\title{
Investigation of nickel ions adsorption by Acacia auriculiformis components
}

\author{
Tatiana R. Denisova', Irina Ya. Sippel', Kim Thi Thoa Nguyen², \\ Rumia Z. Galimova², Ildar G. Shaikhiev²
}

\author{
${ }^{1}$ Department of Chemistry and Ecology, Kazan Federal University, Kazan, Russia, ${ }^{2}$ Department of Chemistry, \\ Kazan National Research Technological University, Kazan, Russia
}

\begin{abstract}
Aim: The isotherms of the adsorption of nickel (Ni) (II) ions from model aqueous solutions with the initial concentration of metal ions from 0 to $1500 \mathrm{mg} / \mathrm{dm}^{3}$ by crushed bark, wood sawdust, and leaves of trees of Acacia auriculiformis in static mode are obtained. It has been established that crushed acacia bark has the largest adsorption capacity with respect to $\mathrm{Ni}$ II ions $(7 \mathrm{mg} / \mathrm{g})$, and the lowest adsorption capacity has acacia leaves $(4 \mathrm{mg} / \mathrm{g})$. Adsorption isotherms were calculated using Langmuir, Freundlich, Dubinin-Radushkevich, Temkin, Flory-Huggins, Harkins-Jura, and Frenkel-Halsey-Hill models. Materials and Methods: The sorption properties of leaves, sawdust of wood, and crushed bark of $A$. auriculiformis were studied in the static adsorption regime using model aqueous solutions of Ni sulfate (II) with initial concentrations of $\mathrm{Ni}^{2+}$ ions from 0 to $1500 \mathrm{mg} / \mathrm{dm}^{3}$. Results: It is found that the isotherms of the adsorption of Ni ions by leaves, wood sawdust, and crushed bark are most adequately described by the Dubinin-Radushkevich model with the approximation coefficients $\mathrm{R}^{2}=0.988$, $\mathrm{R}^{2}=0.988$, and $\mathrm{R}^{2}=0.982$, respectively, indicating that the process takes place both in the pores and on the surface of sorption material. The thermodynamic parameters of the adsorption process are calculated. Conclusions: The obtained values of Gibbs energy $\Delta \mathrm{G}$ and the adsorption energy $\mathrm{E}$ indicate that the limiting adsorption stage of $\mathrm{Ni}$ (II) ions by $A$. auriculiformis components is physical adsorption.
\end{abstract}

Key words: Acacia auriculiformis, bark, leaves, nickel ions, sawdust, sorption capacity, sorption isotherms

\section{INTRODUCTION}

A steadily increasing pollution of the environment with pollutants of different origin causes tension in the world community. A special group of toxic pollutants is heavy metal ions (HMI) that enter natural water sources as part of insufficiently purified sewage. Among all the known methods of extracting HMI, the reagent method, which consists in the addition of chemical reagents, leading to the formation of poorly water-soluble compounds of the HMI and the precipitation of the latter into sediment, has been most widely used. ${ }^{[1]}$ The disadvantage of the method is a large consumption of reagents and an increase in the salinity of the effluent to be treated. The ion exchange method of HMI extraction contributes to the formation of a large amount of concentrated effluents after the regeneration of ion exchange resins. ${ }^{[2]}$

Sorption purification is widely used for the removal of pollutants of various origins including HMI, from wastewater, and natural waters. ${ }^{[3,4]}$ However, a deterrent to the use of this method is the high cost of the sorbents applied, usually activated carbons, and the need for regeneration of the latter, which contributes to a sharp increase in the cost of treatment.

Recently, to eliminate the above-mentioned shortcomings of sorption purification, the attention of researchers to alternative sorption materials has increased, among which cellulosecontaining waste from plant raw materials processing occupy the leading position. ${ }^{[5-7]}$ Of particular interest is wastes from the processing of woody biomass (sawdust, shavings, and chips) and components of trees and shrubs. Various studies have shown that sawdust,,$^{[8-9]}$ bark,,${ }^{[10-13]}$ foliage, ${ }^{[14-16]}$ and other components of hardwood and coniferous trees contribute to the extraction of HMI from aqueous solutions.

Address for correspondence:

Tatiana R. Denisova, Department of Chemistry and Ecology, Kazan Federal University, Kremlyovskaya Street, 18, Kazan, Respublika Tatarstan, Russia, 420008. E-mail: Timiryanova.tanya@yandex.ru

Received: $22-11-2018$

Revised: 07-12-2018

Accepted: 16-12-2018 
Of particular interest is tree species that contain tannins, which react with the HMI and form water-insoluble compounds. For example, earlier it was shown, in particular, that the components of oak ${ }^{[17]}$ and acacia ${ }^{[18]}$ tree and shrub species effectively remove HMI from aqueous media.

In connection with the foregoing, it seemed interesting to investigate the sorption of HMI components of trees of the genus Acacia. The choice of the latter is due to the fact that components of some types of acacias and extracts from its bark are used to remove various pollutants including HMI, from natural and wastewater.

$\mathrm{Ni}$ is an essential for living organisms microelement, but its excess intake has a negative impact on human health, including Ni compounds having a carcinogenic effect. Ni can cause respiratory diseases, diseases of the cardiovascular system, has a negative effect on the process of hematopoiesis, binds to serum gamma globulin in the blood, inhibits carbohydrate metabolism, and the synthesis of certain enzymes. ${ }^{[19]} \mathrm{Ni}$ salts cause damage to the skin.

The main source of (Ni) (II) ions entering water bodies is poorly purified effluents from galvanic plants, mine waters, etc.

On the basis of the foregoing, in this paper, we studied the adsorption of $\mathrm{Ni}$ (II) ions from model aqueous solutions using sawdust of wood, bark, and foliage of Acacia auriculiformis. The choice of the latter is due to the fact that this type of tree is a typical representative of the flora of the region of one of the authors of this message. Earlier, the use of components of this tree species for the sorption removal of As (III) ions ${ }^{[20]}$ and $\mathrm{Cu}$ (II) ions ${ }^{[21]}$ has been reported.

\section{MATERIALS AND METHODS}

The sorption properties of leaves, sawdust of wood, and crushed bark of $A$. auriculiformis were studied in the static adsorption regime using model aqueous solutions of $\mathrm{Ni}$ sulfate (II) with initial concentrations of $\mathrm{Ni}^{2+}$ ions from 0 to $1500 \mathrm{mg} / \mathrm{dm}^{3}$. Based on the values of initial and equilibrium concentrations, the adsorption capacity of materials is determined by the formula 1 :
$A=\left(C_{s}-C_{e}\right) \cdot \mathrm{V} / \mathrm{m}$

Where, $\mathrm{A}$ is the adsorption capacity for $\mathrm{Ni}^{2+}$ ions $(\mathrm{mmol} / \mathrm{g}), \mathrm{Cs}$ is the initial concentration of $\mathrm{Ni}^{2+}$ ions $\left(\mathrm{mmol} / \mathrm{dm}^{3}\right)$, Ce is the $\mathrm{Ni}^{2+}$ ion concentration after adsorption $\left(\mathrm{mmol} / \mathrm{dm}^{3}\right), \mathrm{V}$ is the solution volume $\left(\mathrm{dm}^{3}\right)$, and $\mathrm{m}$ - mass of the sorption material $(\mathrm{g})$.

\section{RESULTS AND DISCUSSION}

The isotherms of the adsorption of $\mathrm{Ni}^{2+}$ ions by the investigated materials are shown in Figure 1. It is obvious that the largest adsorption capacity in relation to the HMI is the ground acacia bark $(0.119 \mathrm{mmol} / \mathrm{g}$ or $7 \mathrm{mg} / \mathrm{g})$, to a lesser degree, sawdust of acacia wood $(0.080 \mathrm{mmol} / \mathrm{g}$ or $4.7 \mathrm{mg} / \mathrm{g})$ and the acacia leaves $(0.068 \mathrm{mmol} / \mathrm{g}$ or $4 \mathrm{mg} / \mathrm{g})$ have the lowest adsorption capacity.

The obtained adsorption isotherms were processed using the Langmuir, Freundlich, Temkin, Flory-Huggins, DubininRadushkevich, Harkins-Jura, and Frenkel-Halsey-Hill models. The obtained equations and their approximation rates $\left(\mathrm{R}^{2}\right)$ are indicated in Table 1. As Table 1 shows, the isotherms of the adsorption of $\mathrm{Ni}$ (II) ions by leaves, sawdust, and ground acacia bark can be described by

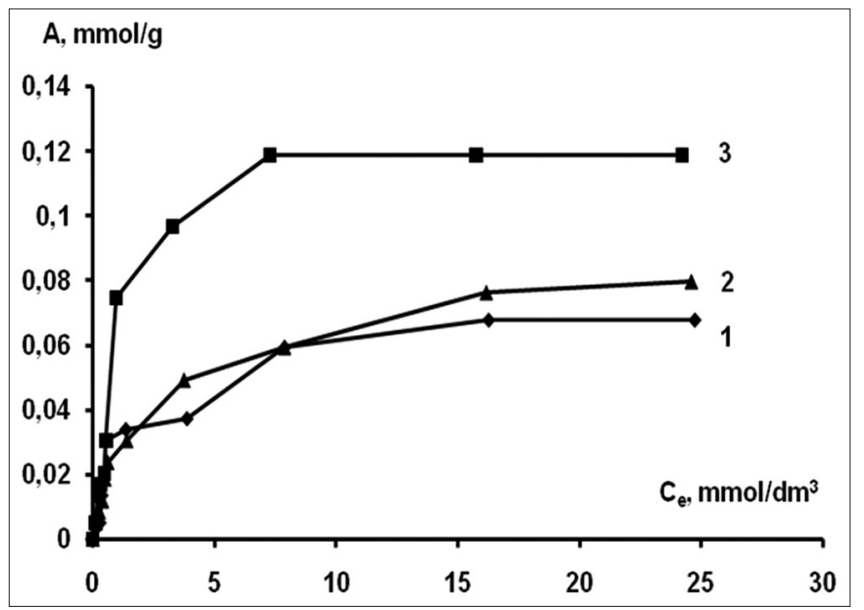

Figure 1: Isotherms for adsorption of nickel (II) ions by (1) acacia leaves, (2) acacia sawdust, (3) acacia crushed bark

Table 1: Adsorption isotherms equations and approximation coefficients

\begin{tabular}{lccc} 
Sorption model & \multicolumn{3}{c}{ Sorbent } \\
\cline { 2 - 4 } & \multicolumn{1}{c}{ Acacia leaves } & Acacia sawdust & Acacia crushed bark \\
\hline Langmuir & $\mathrm{y}=39.25 x+1.588, \mathrm{R}^{2}=0.899$ & $\mathrm{y}=22.50 \mathrm{x}+14.43, \mathrm{R}^{2}=0.981$ & $\mathrm{y}=21.02 \mathrm{x}+0.113, \mathrm{R}^{2}=0.948$ \\
Freundlich & $\mathrm{y}=0.509 \mathrm{x}-1.721, \mathrm{R}^{2}=0.783$ & $\mathrm{y}=0.500 \mathrm{x}-1.679, \mathrm{R}^{2}=0.934$ & $\mathrm{y}=0.553 \mathrm{x}-1.475, \mathrm{R}^{2}=0.844$ \\
Dubinin-Radushkevich & $\mathrm{y}=-2 \mathrm{E}-08 \mathrm{x}-1.901, \mathrm{R}^{2}=0.988$ & $\mathrm{y}=-2 \mathrm{E}-08 \mathrm{x}-1.758, \mathrm{R}^{2}=0.988$ & $\mathrm{y}=-2 \mathrm{E}-08 \mathrm{x}-1.519, \mathrm{R}^{2}=0.982$ \\
Temkin & $\mathrm{y}=0.013 \mathrm{x}-0.024, \mathrm{R}^{2}=0.949$ & $\mathrm{y}=0.015 \mathrm{x}-0.031, \mathrm{R}^{2}=0.983$ & $\mathrm{y}=0.025 \mathrm{x}-0.048, \mathrm{R}^{2}=0.928$ \\
Flory-Huggins & $\mathrm{y}=-14.40 \mathrm{x}-2.381, \mathrm{R}^{2}=0.659$ & $\mathrm{y}=-19.55 \mathrm{x}-2.845, \mathrm{R}^{2}=0.941$ & $\mathrm{y}=-11.57 \mathrm{x}-2.536, \mathrm{R}^{2}=0.757$ \\
Harkins-Jura & $\mathrm{y}=-21,749 \mathrm{x}+17,598, \mathrm{R}^{2}=0.37$ & $\mathrm{y}=-10,224 \mathrm{x}+8446, \mathrm{R}^{2}=0.459$ & $\mathrm{y}=-8170 \mathrm{x}+6188, \mathrm{R}^{2}=0.309$ \\
Frenkel-Halsey-Hill & $\mathrm{y}=0.509 \mathrm{x}-3.964, \mathrm{R}^{2}=0.783$ & $\mathrm{y}=0.500 \mathrm{x}-3.866, \mathrm{R}^{2}=0.934$ & $\mathrm{y}=0.553 \mathrm{x}-3.397, \mathrm{R}^{2}=0.844$ \\
\hline
\end{tabular}


the Dubinin-Radushkevich adsorption equations with approximation rates of $0.988,0.988$, and 0.982 , respectively, and Temkin's equations can also be used to describe these processes.

Consequently, it can be assumed that the process of the adsorption of $\mathrm{Ni}$ (II) ions by leaves, sawdust, and ground acacia bark proceeds both in the pores and on the inhomogeneous surface of the adsorption material.

Visually, the correspondence of adsorption models to the process under investigation can be demonstrated by constructing theoretical isotherms of adsorption processes using the equations of adsorption models with recalculation into theoretical values $C_{e}$ and $A$ and correlating theoretical isotherms with experimentally obtained data.

Adsorption isotherms constructed from experimental and theoretical data for the processes of the adsorption of $\mathrm{Ni}^{2+}$ ions by leaves, sawdust, and ground acacia bark are presented in Figures 2-4, respectively.

Figures 2-4 show that the theoretical isotherms of the Dubinin-Radushkevich and Temkin monomolecular models of the adsorption of $\mathrm{Ni}^{2+}$ ions by leaves, sawdust, and ground acacia bark describe well the experimental data, which confirms the results of calculating the equations and correlation coefficients of the adsorption models presented in Table 1.

Based on the obtained adsorption equations and the constants of the Langmuir and Dubinin-Radushkevich models, the thermodynamic constants of the adsorption of $\mathrm{Ni}^{2+}$ ions by the acacia leaves, sawdust, and ground bark, describing the mechanism of adsorption processes, are determined by formulas 2 and 3 .

$$
E=(-2 \beta)^{\frac{-1}{2}}
$$

$\Delta \mathrm{G}^{\mathrm{o}}=\mathrm{R} \cdot \mathrm{T} \cdot \ln \mathrm{K}_{\mathrm{L}}$

Where, $E$ is the sorption energy $(\mathrm{J} / \mathrm{mol}), \beta$ is the DubininRadushkevich constant, $\Delta G$ is the Gibbs energy $(\mathrm{J} / \mathrm{mol}), R$ is the universal gas constant, and $K_{L}$ is the Langmuir constant.
It is known that the values of Gibbs energy $(\Delta G)<20 \mathrm{kJmol}$ by module, as well as the adsorption energy $(E)<8 \mathrm{~kJ} / \mathrm{mol}$, indicate the process of physical adsorption; hence, the data presented in Table 2 indicate the physical nature of the adsorption of HMI by the sorption materials under study.

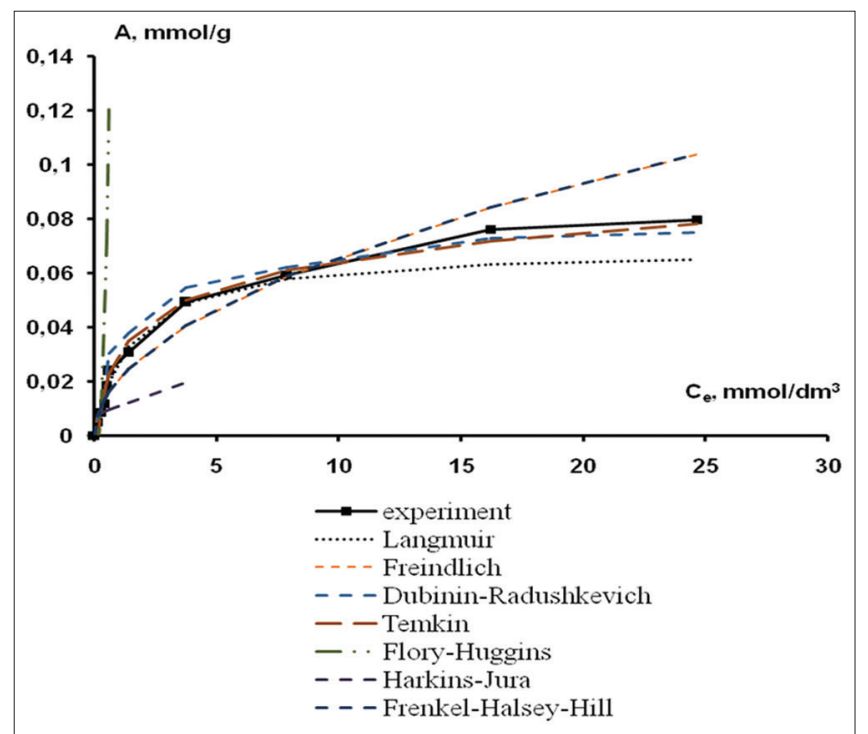

Figure 2: Isotherms of the adsorption of nickel (II) ions by acacia leaves

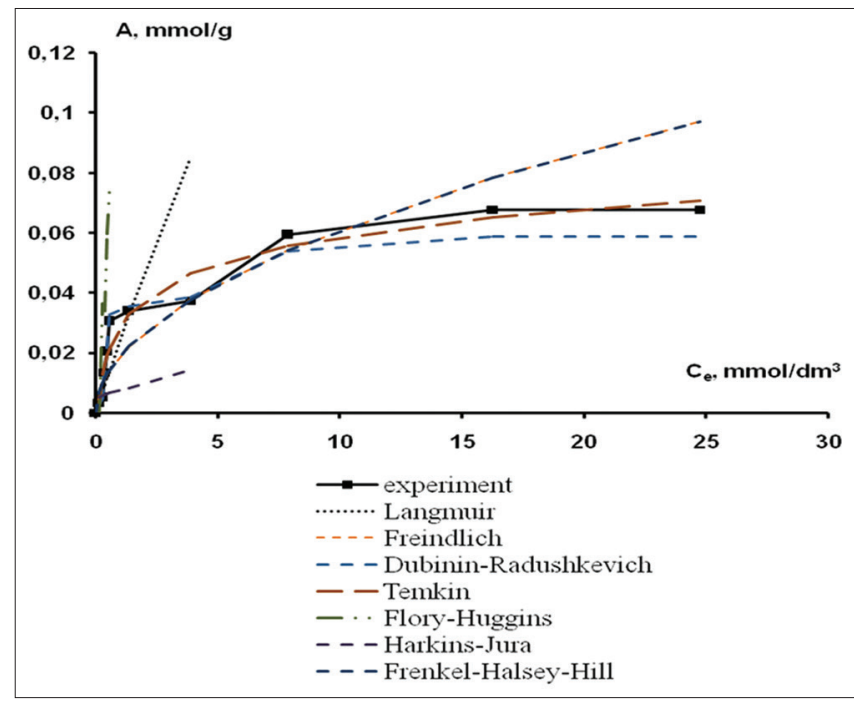

Figure 3: Isotherms of the adsorption of Nickel (II) ions by acacia sawdust

Table 2: Values of thermodynamic parameters for the process of $\mathrm{Ni}$ ions adsorption by acacia leaves, sawdust, and crushed bark

\begin{tabular}{lccl} 
Sorbent & $\Delta \mathbf{G}, \mathbf{k J} / \mathbf{m o l}$ & $\mathbf{E}, \mathbf{k J} / \mathbf{m o l}$ & Conclusion \\
\hline Acacia leaves & -7.947 & 5.001 & $|\Delta \mathrm{G}|<20 \mathrm{~kJ} / \mathrm{mol}, \mathrm{E}<8 \mathrm{~kJ} / \mathrm{mol}$, physical adsorption \\
$\begin{array}{l}\text { Acacia sawdust } \\
\begin{array}{l}\text { Acacia crushed } \\
\text { bark }\end{array}\end{array}$ & -1.001 & 5.001 & $|\Delta \mathrm{G}|<20 \mathrm{~kJ} / \mathrm{mol}, \mathrm{J}<8 \mathrm{~kJ} / \mathrm{mol}$, physical adsorption \\
\hline
\end{tabular}

Ni: Nickel 


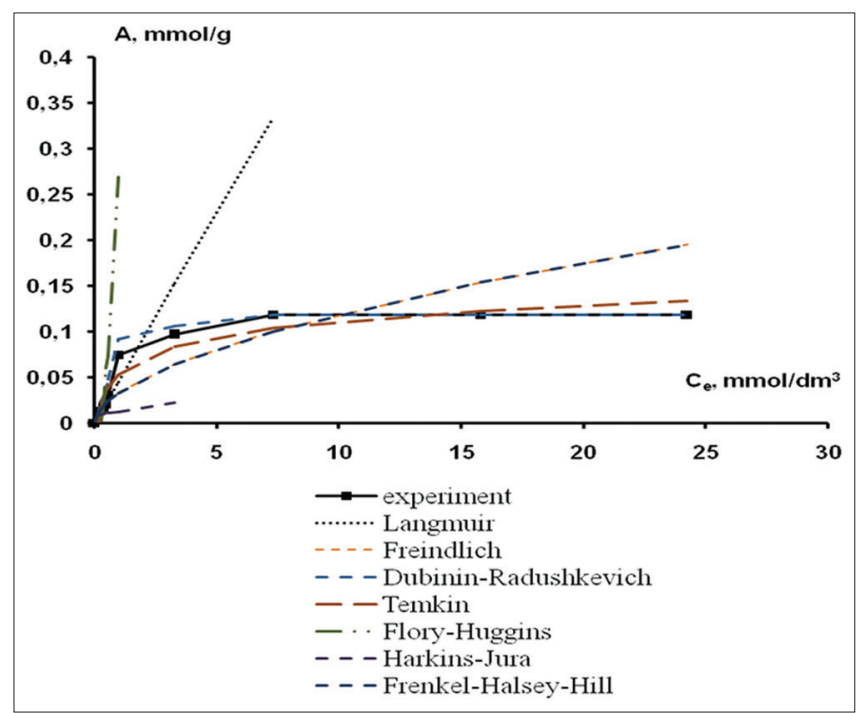

Figure 4: Isotherms of the adsorption of Nickel (II) ions by acacia crushed bark

\section{SUMMARY}

The conducted experiments made it possible to obtain adsorption isotherms for $\mathrm{Ni}^{2}+$ ions with various components of $A$. auriculiformis and then carry out their calculation using Langmuir, Freundlich, Temkin, Dubinin-Radushkevich, Flory-Huggins, Harkins-Jura, and Frenkel-Halsey-Hill models. It is found that the isotherms of the sorption of $\mathrm{Ni}$ (II) ions by leaves, sawdust of wood, and crushed bark of A. auriculiformis are most adequately described by the Dubinin-Radushkevich model. The thermodynamic parameters of the sorption process are calculated. It was revealed that physical sorption is the limiting stage of the sorption of $\mathrm{Ni}^{2+}$ ions by the components of A. auriculiformis.

\section{CONCLUSIONS}

Thus, the possibility of using sawdust of wood and bark as well as the foliage of $A$. auriculiformis as sorption materials with respect to $\mathrm{Ni}^{2+}$ ions has been shown, which makes it possible to obtain cheap and environmentally friendly sorption material based on wood waste. The largest adsorption capacity with respect to these ions is provided by the crushed acacia bark.

\section{ACKNOWLEDGMENTS}

The work is performed according to the Russian Government Program of Competitive Growth of Kazan Federal University.

\section{REFERENCES}

1. Fu F, Wang Q. Removal of heavy metal ions from wastewaters:A review.J Environ Manage 2011;92:407-18.
2. Dabrowski A, Hubicki Z, Podkościelny P, Robens E. Selective removal of the heavy metal ions from waters and industrial wastewaters by ion-exchange method. Chemosphere 2004;56:91-106.

3. Jiuhui QU. Research progress of novel adsorption processes in water purification: A review. J Environ Sci (China) 2008;20:1-3.

4. Rao GP, Lu C, Su F. Sorption of divalent metal ions from aqueous solution by carbon nanotubes: A review. Sep Purif Technol 2007;58:224-231.

5. Khan NA, Ibrahim S, Subramaniam P. Elimination of heavy metals from wastewater using agricultural wastes as adsorbents. Malays J Sci 2004;23:43-51.

6. Wang J, Chen C. Biosorbents for heavy metals removal and their future. Biotechnol Adv 2009;27:195-226.

7. Khan MA, Rao RA, Ajmal M. Heavy metal pollution and its control through nonconventional adsorbents (19982007): A review. J Int Environ Appl Sci 2008:3:101-41.

8. Bulut Y, Tez Z. Removal of heavy metals from aqueous solution by sawdust adsorption. J Environ Sci (China) 2007;19:160-6.

9. Sćiban M, Klasnja M, Skrbić B. Modified softwood sawdust as adsorbent of heavy metal ions from water. J Hazard Mater 2006;136:266-71.

10. Sen A, Pereira H, Olivella MA, Villaescusa I. Heavy metals removal in aqueous environments using bark as a biosorbent. Int J Environ Sci Technol 2015;12:391-404.

11. Al-Asheh S, Duvnjak Z. Sorption of cadmium and other heavy metals by pine bark. J Hazard Mater 1997;56:35-51.

12. Šćiban $M$, Radetić $B$, Kevrešan Ž, Klašnja M. Adsorption of heavy metals from electroplating wastewater by wood sawdust. Bioresour Technol 2007;98:402-9.

13. Khokhotva OP, Westholm LJ. The impact of surface properties of modified pine bark on the mechanism of sorption of heavy metals from aqueous media. J Water Chem Technol 2017;39:148-54.

14. Tiwari P, Vishwakarma MC, Joshi SK, Sharma H, Bhandari NS. Adsorption of $\mathrm{Pb}$ (II), $\mathrm{Cu}$ (II), and $\mathrm{Zn}$ (II) Ions onto Urtica dioica leaves (UDL) as a low cost adsorbent: Equilibrium and thermodynamic studies. Mod Chem 2017;5:11-8.

15. Lee SY, Choi HJ. Persimmon leaf bio-waste for adsorptive removal of heavy metals from aqueous solution. J Environ Manag 2108;209:382-92.

16. Subbarayudu K, Prathibha R, Rao CN, Sivakumar K, Venkateswarlu P. Adsorption of lead and zinc on Curcuma longa leaf powder from aqueous solutions. Indian J Adv Chem Sci 2017;5:76-80.

17. Shaikhiev IG. Use of tree components of the genus Quercus as sorption materials for removal of pollutants from water. A review of the literature. Bull Technol Univ 2017;20:151-60.

18. Shaikhiev IG, Thoa NT, Shaikhieva KI. Use of components of trees of the genus Acacia to remove pollutants from natural and waste water. 1. Ions of heavy metals. Bull Technol Univ 2017;20:171-9. 
19. Lazarev NV, editor. Harmful Substances in the Industry. Vol. 1. London: Academic Press; 1976. p. 590.

20. Mukul SA, Parvez K, Subhan A. Biosorption of As (III) from aqueous solution by Acacia auriculiformis leaves. Sci Iran 2103;20:1871-80.

21. Thoa NT, Sidorovnina OO, Zamalieva LA,
Miftakhova FR, Galimova RZ, Shaikhiev IG, et al. Study of sorption of copper ions by the components of Acacia auriculiformis. Bull Technol Univ 2017;20:159-62.

Source of Support: Nil. Conflict of Interest: None declared. 